\title{
People's Republic of China's economic diplomacy instruments in Southeast Asia - chosen aspects
}

\author{
Paulina SZYJA 1, Łukasz STACH ${ }^{2}$ \\ ${ }^{1}$ Pedagogical University of Cracow, Cracow, Poland, paulina.szyja@up.krakow.pl \\ ${ }^{2}$ Pedagogical University of Cracow, Cracow, Poland, lukasz.stach@up.krakow.pl
}

\begin{abstract}
The paper presents the issue of China's use of economic diplomacy instruments in Southeast Asia. The authors have chosen those they consider to be the most important ones, and their use in Southeast Asian countries has been presented. The goal of the paper is analyzing the role of selected economical instruments used by the China's government in Southeast Asian countries, and answering the following questions: which economical instruments are used by China in the region?; how important is People's Republic of China as a trade partner for SEA states?; what is the role and scale of Chinese direct investment in Southeast Asian countries, including the Belt and Road Initiative?; what are the consequences of China's activities for SEA countries? The methodology of the paper is based on literature review and statistical data analysis. The results show that China has become an important trade partner and a source of FDI for the SEA region, especially for less developed states. Countries such as Cambodia, Lao PDR or Myanmar (which are corrupt and fragile) are areas of PRC economic expansion, which also enhances PRC political influence in the region.
\end{abstract}

Keywords: China; Southeast Asia; trade; FDI; geoeconomic strategy;

JEL Classification: O53; O57; P45; P48

\section{Introduction}

China is a sleeping giant. Let her sleep, for when she wakes she will move the world - Napoleon Bonaparte is supposed to have said that over 200 years ago. Actually, even if these words were not spoken, China woke up and transformed the world economy and politics. After the period of 'national humiliation' (Wang 2012) (when China was a victim of Western colonialism, tsarist Russia's expansionism, and Japanese militarism and imperialism) and socio-economical experiments by Chairman Mao Zedong, in the end of 1970s People's Republic of China (PRC) initiated pro-market economic reforms, including the 'Open Door policy' and trade liberalisation. The results were spectacular. According to the U.S. Congressional Research Service, since opening up to foreign trade and investment and implementing free-market reforms in 1979 China has been among the world's fastest-growing economies, with real annual gross domestic product (GDP) growth averaging 9.5\% through 2018, a pace described by the World Bank as "the fastest sustained expansion by a major economy in history". Such growth has enabled China, on average, to double its GDP every eight years and helped raise an estimated 800 million people out of poverty. China has become the world's largest economy (on a purchasing power parity basis), manufacturer, merchandise trader, and a holder of foreign exchange reserves (Morrison 2019). Table 1 presents the value of China's GDP, export and import in 1979 (the beginning of the transition), 1989, 1999, 2009, and 2018.

Table 1. People's Republic of China's GDP, import and export value in 1979, 1989, 1999, 2009, and 2018 (USD) (Word Bank)

\begin{tabular}{cccccc}
\hline & $\mathbf{1 9 7 9}$ & $\mathbf{1 9 8 9}$ & $\mathbf{1 9 9 9}$ & $\mathbf{2 0 0 9}$ & $\mathbf{2 0 1 8}$ \\
\hline GDP (current USD) & $178.281 \mathrm{bn}$ & $347.768 \mathrm{bn}$ & $1.094 \mathrm{tn}$ & $5.1 \mathrm{tn}$ & $13.608 \mathrm{tn}$ \\
GDP (current international & -- & $1.121 \mathrm{tn}^{*}$ & $3.343 \mathrm{tn}$ & $11.12 \mathrm{tn}$ & $25.362 \mathrm{tn}$ \\
USD) & & & & & \\
GDP per capita (current USD) & 184 & 311 & 873 & 3,833 & 9,772 \\
Exports of goods and services & $9.204 \mathrm{bn}$ & $41.191 \mathrm{bn}$ & $198.699 \mathrm{bn}$ & $1.25 \mathrm{tn}$ & $2.656 \mathrm{tn}$
\end{tabular}


(current USD)

$\begin{array}{lllll}\text { Imports of goods and services } \quad 10.561 \mathrm{bn} & 46.119 \mathrm{bn} \quad 168.058 \mathrm{bn} \quad 1.03 \mathrm{tn} \quad 2.549 \mathrm{tn}\end{array}$ (current USD)

* Data for 1990

Such economic growth has significantly enhanced PRC regional and international position, which led to a rise of so-called 'fear of China'. At the international level, the United States started to consider China to be a threat for the U.S. global dominance, and the PRC is perceived mostly as an economic and technological rival; however, growing China's military capabilities are also feeding that fear (Ezrati 2018). In 2011, U.S. president Barack Obama announced the 'pivot to Asia' (Manyin et al. 2012, Chen 2013: 39), and in 2018 Donald Trump began to set tariffs and trade barriers on China. It was a clear sign of an ongoing conflict between the two largest world's economies. At the regional level, Japan, South Korea and Taiwan are concerned about growing PRC potential in political, economic and military terms. For Southeast Asian (SEA) countries [...] the rise of China is a mixed blessing. While they have benefited greatly for its economic ties, they are alarmed about more assertive China in their neighborhood (Cho and Park 2013: 69). The PRC is more assertive in the South China Sea's territorial disputes, and 'China's peaceful development' (Yi 2005: 78-79) causes some concerns amongst SEA political elites and societies, too. For instance, in August 2018, Malaysian prime minister Mahathir Mohamad alarmed that PRC Belt and Road Initiative (BRI) may be a new form of colonialism and that the Sino-Malaysian deals signed under the former cabinet had been unfair and would leave Malaysia indebted to China (ABC News 2018). Moreover, Indonesia, the Philippines and Thailand raised concerns about their growing dependency on PRC investment, especially in infrastructure (Taj 2019). In fact, since the PRC emerged as a great economic and political power, the balance of power in Asia, including the Southeast Asian region, changed. The RAND Corporation highlights the fact that China considers itself a 'Great Power' and that China's 'Grand Strategy' strives for three main objectives: (1) to control the periphery and ward off threats to the ruling regime; (2) to preserve domestic order and well-being in the face of different forms of social strife; and (3) to attain or maintain geo-political influence as a major, or even primary, state (Swaine and Tellis 2000).

Southeast Asia is composed of eleven countries (Brunei, Cambodia, East Timor (Timor-Leste), Indonesia, Lao PDR, Malaysia, Myanmar (Burma), the Philippines, Singapore, Thailand and Vietnam). Ten countries are members of the Association of Southeast Asian Nations (ASEAN), and East Timor is an observer state. In the last decade, SEA experienced a fast economic growth, which accounted for a growing importance of the whole region. Southeast Asia has a significant strategic importance for the PRC in political, economic and military terms. Controlling the SEA region secures the PRC south-east borders, where important cities and industrial centers are located. Moreover, it is a region of potential projection of China's influence and securing the PRC dominant position would be a step towards establishing China a world power, responsible for shaping the international order. Moreover, SEA is economically vibrant and possesses a close communication with China's coastal provinces, which are important for Beijing's rapid economic development (Stuart-Fox 2004: 117). Additionally, two waterways located in SEA (the Strait of Malacca and the South China Sea) play a key role for PRC economic development and trade exchange. About $80 \%$ of China's crude oil import passes through the Strait of Malacca and the South China Sea. Particularly, the Strait of Malacca became a PRC strategic chokepoint due to its geography. It is a narrow waterway between the Malay Peninsula and the Indonesian island of Sumatra. During a conflict, it could be easily blocked by hostile forces and the PRC could be cut off from strategic energy resources, mostly crude oil (Zhong 2015, 88-89). This so-called 'Malacca Dilemma' is a challenge for PRC security and development especially in a long-term perspective - and therefore the reinforcement of China's influence in the region would reduce the risk. A similar situation occurs in the South China Sea basin, which is a crucial waterway not only for Beijing, but also for other Far Eastern countries, including strong economies such as Japan, South Korea or Taiwan. Taking control over the SCS would significantly improve PRC geopolitical position and secure a key sea line of communication (SLOC). Moreover, some SEA countries are strategically important for Beijing. For instance, the Philippines form part of so-called 'first-island chain', which stretches from the Kuril Islands through Japanese Archipelago, 
Taiwan and the Philippines to Borneo. From Beijing's perspective, the island chain idea stimulates China's fear of strategic encirclement, underscores the geostrategic value of Taiwan, frames Chinese military option at sea, and engages important economic interests (Yoshikara 2012: 293). For PRC economic penetration, the Philippines are much easier target than Japan or Taiwan, especially under the Rodrigo Duterte's presidency (he was elected in 2016, as the 16th president of the Philippines), who leads more pro-Chinese policy than his predecessor. Thailand attracts PRC attention due to the Kra Isthmus. Building a canal through the Kra Isthmus (the narrowest part of the Malay Peninsula) would enable ships to bypass the Strait of Malacca, and for Beijing this has a strategic significance (Menon 2018). Myanmar is a place of Sino-Indo geopolitical rivalry in the Indian Ocean region. Myanmar being a PRC 'client state' would enhance China's presence in the Indian Ocean (Malik 1994: 142-144).

Generally, China has some tools which could help it to achieve its goals in the SEA region: diplomacy, economy, and military power. Despite the fact that growing Beijing's military capabilities give the PRC significant advantage over the armed forces of any other SEA country, using the People's Liberation Army would be the worst option for the PRC. A military conflict in the region could destroy the fruits of China's economic reform and the image of the PRC as a 'status quo power' (Cheng 2013: 54). Additionally, China cultivates its 'soft power' and puts an effort into building a positive image of the whole country (Cheng 2013: 59-60). Thus, although powerful PRC armed forces are one of the pillars of China being a world power, using the army recklessly could only complicate Beijing's plans.

China's economic dominance over SEA would be the most effective and politically profitable, and therefore using economic diplomacy is an obvious solutions for the PRC leaders. Recently, economic dominance has been associated mostly with financial power. Increasing capital mobility combined with the developing countries' need for money may lead to a situation in which a large part of manufacturing industry, key infrastructure, natural resources or financial institutions fall into the hands of foreign owners. It may lead to the situation in which a country becomes dependent on foreign states (Luard 1984). According to Vannarith Chheang (2018), economic statecraft (using economic power to achieve strategic goals), combined with institutional statecraft (the development of multilateral mechanism led by China), are major components of Beijing's economic diplomacy.

In the SEA region, China uses various tools of economic diplomacy. The most important ones include:

1. Trade (overdependence on China as a major trade partner for the SEA countries, dominant Beijing's trading position and very strong balance of payment).

2. Direct foreign investments (the PRC as the key investor).

3. Financial aid (China as an important donor).

4. Credits and loans (overdependence on China as a source of money, risk of the debt trap).

Moreover, the Belt and Road Initiative (BRI), widely discussed and analysed (Google Scholar has shown over 19,500 results, EBSCO 950, and the Web of Science Core Collection 1,232 ones), is also a part of Beijing's economic diplomacy (Chheang 2018) and - despite all the risk and uncertainties - it will improve PRC position, both in the SEA region and international environment (Wang 2016). The Belt and Road Initiative (also called One Belt, One Road) is an ambitious PRC project to build the Silk Road Economic Belt and the 21st Century Maritime Silk Road. The aim of the programme, announced by China's President Xi Jinping in 2013, is construction of infrastructure. On land, China aims to connect its undeveloped regions to Europe through Central Asia (the Silk Road Economic Belt). The 21st Century Maritime Silk Road connects China's southern provinces with South East Asia, the Indian Ocean, part of East Africa, the Red Sea, and the Mediterranean Sea through ports and railways (Cai 2017). In the SEA region, the PRC promotes the China-Indochina Peninsula Economic Corridor, which aims to strengthen the cooperation between China and the Indochina states, and to support trade between the PRC and ASEAN countries, mostly by developing transport network (motorways, railways, and air connection (OBOReurope)). Belt and Road Initiative (BRI) hopes to deliver trillions of dollars in infrastructure financing to Asia, Europe, and Africa. If the initiative follows Chinese practices to date for infrastructure financing, which often entail lending to sovereign borrowers, then BRI raises the risk of debt distress in some borrower countries (Hurley et al. 2019: 152). The risk of the 'debt trap' or the debt 
problem is more serious in poorer, more fragile and corrupt SEA states which need credits, financial support or aid to improve their economy. However, weak and corrupt institutions do waste money. For Beijing, such situation creates an opportunity to enhance its political and economic influence in a country with a debt owed to official or quasi-official PRC moneylender.

This article presents chosen instruments of PRC economic diplomacy in the SEA region. In the age of growing US-Sino competition, it is important to analyze PRC activity in the SEA region, especially given the fact that China's policy has become more assertive. The goal of the paper is to analyze the role of selected economical instruments used by the Chinese government in Southeast Asian countries and to answer the following questions: which economical instruments are used by China in the region? How important is People's Republic of China as a trade partner for SEA states? What is the role and scale of Chinese direct investment in Southeast Asian countries, including the Belt and Road Initiative? What are the consequences of China's activities for chosen SEA countries?

A review of literature allows for a few remarks. First of all, more publications address the issue of China's economic involvement in African (Li et al. 2013) and South American countries rather than Southeast Asian ones (Quer 2019). Secondly, publications take into account the issue of the Sino-US or Sino-Japanese competition in selected countries in Southeast Asia (Qi et al. 2019). Thirdly, the issue of Chinese leadership in the region is much more often perceived in the context of political rather than economic influence.

In turn, publications present the issue of economic connection between China and Southeast Asia, as follows:

- Southeast Asian direct investment in China (Samphantharak 2011; Buckley et al. 2010),

- Specificity of investment conditions in SEA countries and types of investment undertaken i.a. by China (Lele 2012),

- The role of Chinese enterprises in the region (Liang, Zhou, Liu 2019; Yutian, Zhenge, Yi 2019),

- China's investment diplomacy (Copper 2016),

- Chinese direct investment in Southeast Asia (Frost, Ho 2005),

- Chinese infrastructure investments in the region (Ganesan 2018),

- Chinese overseas industrial parks (Tao et al. 2018),

- economic relations between SEA countries, e.g. between China and Indonesia (Sinaga 2018) or China and Thailand (Lauridsen 2018),

- Chinese economical initiatives in the region (Ba 2018),

- China's Geoeconomic Strategy in Southeast Asia (Sung 2017),

- Chinese impact on regional institutions (Bünte 2018).

\section{Methodology}

The methodology of the paper is based on literature review and statistical data analysis. The thesis is interdisciplinary since it includes both political and economic aspects, which are interrelated. On the one hand, this interdisciplinarity has a positive dimension since it facilitates explaining many aspects which may be vague from an economist's point of view. On the other hand, it is difficult to estimate to what extent the economic instruments are used to serve economic growth and development, and to what extent they are only aimed at temporary or long-term political purposes.

The authors have chosen indicators such as trade balance, export and import value between SEA and the PRC, as well as the value of Chinese FDI and the scale of public debt in SEA countries. Problem of state fragility and corruption is illustrated by the Fragile State Index (FSI) and the Corruption Perception Index (CPI). Export and import value indicate PRC importance as a trade partner of SEA states. The FDI shows the scale of Chinese economic activity in the region. The scale of public debt, the FSI and the CPI are indicators which illustrate the problem of indebtedness and state fragility in the SEA region.

\section{Results: People's Republic of China's economic diplomacy in Southeast Asia - chosen instruments}


In a European Union's document, the term 'economic diplomacy' has been described as follows: There are at least three strands, each one wider in scope, that are common to all definitions of economic diplomacy: 1) facilitating access to foreign markets for national businesses; 2) attracting foreign direct investment (FDI) to a national territory; and 3) influencing international rules to serve the national interest. (...)The goal can be as narrow as boosting economic growth or as broad as developing geo-political influence and a diplomatic network (EP, Imbert 2017). The document also points out to selection of actors (the state, enterprises) and issues (e.g. natural resources). In Southeast Asia, China has implemented a wide range of economic instruments to become a major power in the region. This, in turn, is supposed to bring specific results (Figure 1), and finally the leadership in the region. As L.S. Lauridsen has emphasized, China has been seeking to expand its regional influence by engaging in regional rule-making and institution building. The two-pronged strategy of setting up new multilateral investment banks and overseas infrastructure projects (...) has lifted regional competition and infrastructure diplomacy to a higher level (Lauridsen 2018: 219).

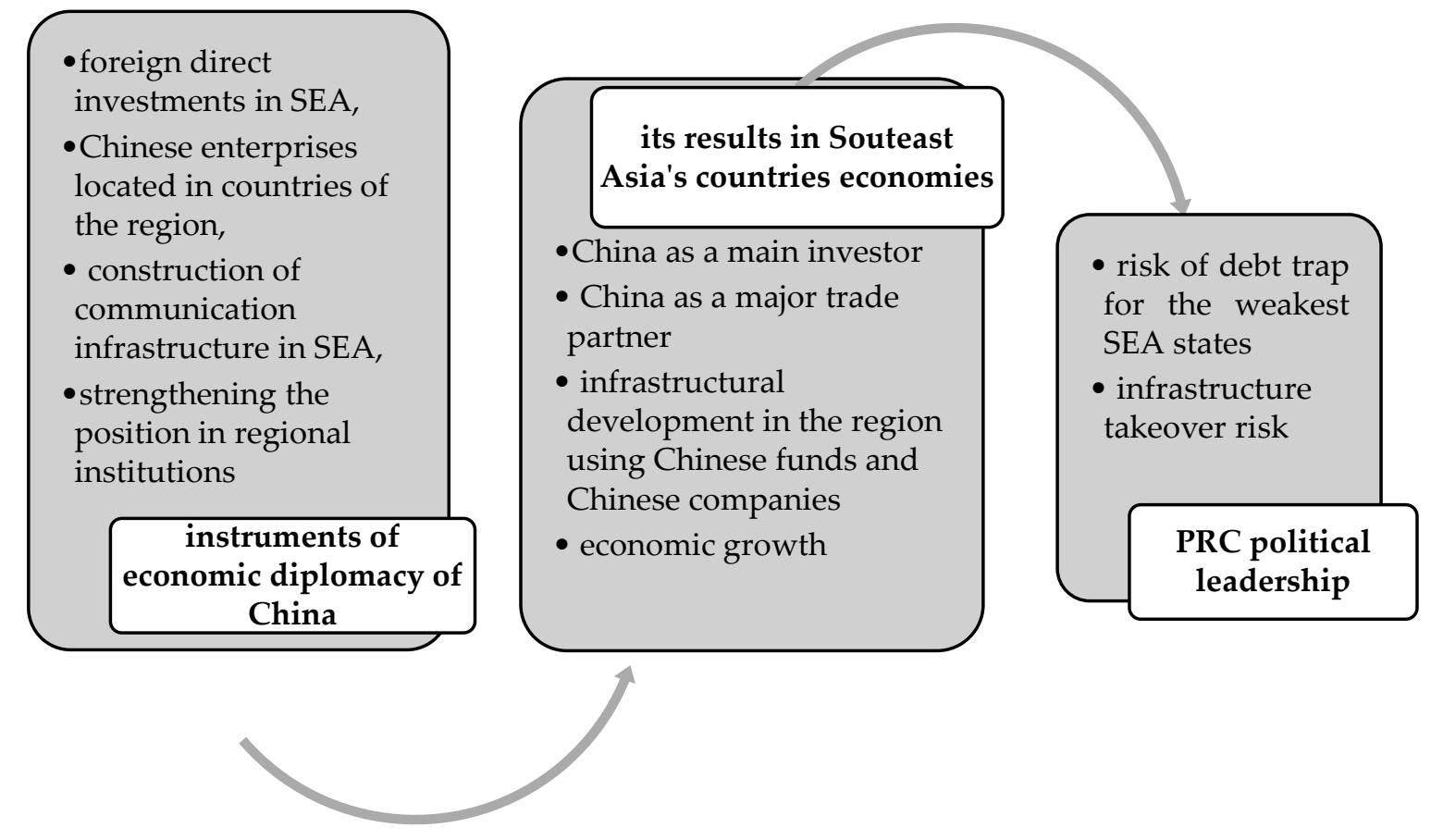

Figure 1. Economic diplomacy as a tool to achieve predominance in the region of Southeast Asia.

In terms of economic potential reflected by the GDP and the GDP PPP, there is a huge gap between the People's Republic of China and SEA countries (table 2). In such conditions, economic diplomacy may be used efficiently, especially in developing states which require investments. Moreover, fragile, corrupt and badly governed countries are more vulnerable. PRC main instruments in low-income countries are direct loans and FDI in commodity-producing industries, energy and transport (Horn et al. 2019: 38-39). Loans form an important PRC economic diplomacy instrument and according to Horn, Reinhart and Treben (2019) [...] about one half of China's large-scale lending to developing countries is "hidden" and not recorded in the main international databases used by researchers and practitioners alike. These hidden overseas debts pose serious challenges for country risk analysis and bond pricing. In the SEA region, Cambodia, Lao PDR, Myanmar and Vietnam are low income developing countries (Horn et al. 2019: 55). Moreover, Cambodia, Lao PDR and Myanmar are classified as fragile states (table 3). Corruption is a widespread problem in all the region, with the exception of Singapore and Brunei (table 3).

Table 2. The GDP and the GDP per capita of SEA countries (data for 2018) (Word Bank)

\begin{tabular}{cccc}
\hline Country & $\begin{array}{c}\text { GDP } \\
\text { (current USD) }\end{array}$ & $\begin{array}{c}\text { GDP PPP (current } \\
\text { international USD) }\end{array}$ & $\begin{array}{c}\text { GDP per capita } \\
\text { (current USD) }\end{array}$ \\
\hline Brunei & $13.567 \mathrm{bn}$ & $34.65 \mathrm{bn}$ & 31,628
\end{tabular}




$\begin{array}{cccc}\text { Cambodia } & 24.572 \mathrm{bn} & 70.753 \mathrm{bn} & 1,512 \\ \text { East Timor } & 2.581 \mathrm{bn} & 9.694 \mathrm{bn} & 2,035 \\ \text { Indonesia } & 1.042 \mathrm{tn} & 3.495 \mathrm{tn} & 3,894 \\ \text { Lao PDR } & 18.131 \mathrm{bn} & 52.547 \mathrm{bn} & 2,567 \\ \text { Malaysia } & 354.348 \mathrm{bn} & 999.405 \mathrm{bn} & 11,239 \\ \text { Myanmar } & 71.215 \mathrm{bn} & 357.819 \mathrm{bn} & 1,326 \\ \text { Philippines } & 330.91 \mathrm{bn} & 952.967 \mathrm{bn} & 3,103 \\ \text { Singapore } & 364.157 \mathrm{bn} & 571.494 \mathrm{bn} & 64,582 \\ \text { Thailand } & 504.993 \mathrm{bn} & 1.32 \mathrm{bn} & 7,274 \\ \text { Vietnam } & 244.948 \mathrm{bn} & 710.312 \mathrm{bn} & 2,564\end{array}$

Table 3. State fragility (the Fragile State Index - FSI) and corruption (the Corruption Perception Index CPI) in SEA states (Fragile State Index Annual Report 2019, Corruption Perception Index 2018)

\begin{tabular}{|c|c|c|c|c|c|}
\hline \multirow[t]{2}{*}{ Country } & \multicolumn{2}{|c|}{ Fragile State Index 2019} & & \multicolumn{2}{|c|}{ Corruption Perception Index 2018} \\
\hline & Score & Rank & & Score & Rank \\
\hline Brunei & 57.5 & 124 & More stable & 63 & 31 \\
\hline Cambodia & 82.5 & 54 & High warning & 20 & 161 \\
\hline East Timor & 85.5 & 41 & High warning & 35 & 105 \\
\hline Indonesia & 70.4 & 93 & Elevated warning & 38 & 89 \\
\hline Lao PDR & 78.7 & 62 & Elevated warning & 29 & 132 \\
\hline Malaysia & 60.5 & 119 & Warning & 47 & 61 \\
\hline Myanmar & 94.3 & 22 & Alert & 29 & 132 \\
\hline Philippines & 83.1 & 50 & High warning & 36 & 99 \\
\hline Singapore & 28.1 & 162 & Sustainable & 85 & 3 \\
\hline Thailand & 73.1 & 77 & Elevated warning & 36 & 99 \\
\hline Vietnam & 66.1 & 109 & Warning & 33 & 117 \\
\hline
\end{tabular}

NB: The higher the place in the FSI, the more fragile a state is. A lower score means lesser fragility of an indexed country. The CPI measures public sector corruption in 180 countries, giving each a score between 0 (highly corrupt) and 100 (very clean). The lower the place in the CPI, the less corrupt a state is.

\subsection{China as a trade partner}

In recent decades, the PRC trade value has expanded enormously and China became the top world exporter and the second largest world importer. For SEA countries, this situation is both opportunity and threat. China is becoming an important sales market for SEA economies (table 5). On the other hand, the PRC significantly increased its export to the region (table 5) and almost all the SEA region has a negative trade balance with the PRC (table 4).

Table 4. Trade balance between SEA countries and the PRC (The Observatory of Economic Complexity)

\begin{tabular}{ccccccc}
\hline & \multicolumn{2}{c}{ Import (bn USD) } & \multicolumn{2}{c}{ Export (bn USD) } & \multicolumn{2}{c}{ Trade balance (bn } \\
USD) \\
Country & $\mathbf{2 0 0 7}$ & $\mathbf{2 0 1 7}$ & $\mathbf{2 0 0 7}$ & $\mathbf{2 0 1 7}$ & $\mathbf{2 0 0 7}$ & $\mathbf{2 0 1 7}$ \\
\hline Brunei & 0.129 & 0.649 & 0.222 & 0.314 & +0.093 & -0.335 \\
Cambodia & 1.01 & 4.77 & 0.056 & 0.991 & -0.950 & -3.77 \\
East Timor & -- & 0.112 & -- & 0.0032 & -- & -0.108 \\
Indonesia & 9.82 & 34.3 & 11.9 & 25.8 & -2.08 & -8.50 \\
Lao PDR & 0.162 & 1.34 & 0.071 & 1.18 & -0.091 & -0.160 \\
Malaysia & 16.4 & 38.1 & 16.9 & 42.5 & +0.5 & +4.4 \\
Myanmar & 1.68 & 8.34 & 0.298 & 4.46 & -1.382 & -3.88 \\
Philippines & 5.16 & 21.9 & 10.3 & 20 & +5.14 & -1.9 \\
Singapore & 30.4 & 42.6 & 17.7 & 50.3 & -12.7 & +7.7
\end{tabular}




\begin{tabular}{lllllll} 
Thailand & 16.1 & 38.3 & 17.5 & 40.7 & +1.4 & +2.4 \\
Vietnam & 11.9 & 70.6 & 3.22 & 39.9 & -8.68 & -30.7 \\
\hline
\end{tabular}

As table 4 shows, only Malaysia, Singapore and Thailand do not have a trade deficit with China, and during the last decade the PRC has improved its trade balance statistics with SEA. Moreover, the PRC is the top import origin for countries such as Brunei, Cambodia, Indonesia, Malaysia, Myanmar, the Philippines, Singapore, Thailand, and Vietnam (table 5).

Table 5 Import and export value of SEA countries, three top import origins and three top export destinations (The Observatory of Economic Complexity)

\begin{tabular}{|c|c|c|c|c|c|c|}
\hline \multirow[t]{2}{*}{ Country } & \multicolumn{2}{|c|}{ Total value* } & \multicolumn{2}{|c|}{ Top three import origins } & \multicolumn{2}{|c|}{$\begin{array}{c}\text { Three top export } \\
\text { destinations }\end{array}$} \\
\hline & Import & Export & Country & Value* & Country & Value $^{*}$ \\
\hline \multirow[t]{3}{*}{ Brunei } & 3.14 & 5.53 & PRC & 0.649 & Japan & 1.68 \\
\hline & & & Singapore & 0.604 & South Korea & 0.795 \\
\hline & & & Malaysia & 0.575 & Malaysia & 0.627 \\
\hline \multirow[t]{3}{*}{ Cambodia } & 12 & 15.8 & PRC & 4.77 & United States & 3.06 \\
\hline & & & Singapore & 2.95 & Germany & 1.78 \\
\hline & & & Hong Kong & 0.908 & United Kingdom & 1.3 \\
\hline \multirow[t]{3}{*}{ East Timor } & 0.651 & 0.108 & Indonesia & 0.202 & Singapore & 0.067 \\
\hline & & & PRC & 0.112 & United States & 0.001 \\
\hline & & & Singapore & 0.085 & Indonesia & 0.008 \\
\hline \multirow[t]{3}{*}{ Indonesia } & 153 & 188 & PRC & 34.3 & PRC & 25.8 \\
\hline & & & Singapore & 17.9 & United States & 19.9 \\
\hline & & & Japan & 13.5 & Japan & 19 \\
\hline \multirow[t]{3}{*}{ Lao PDR** } & 6.22 & 4.7 & Thailand & 4.04 & Thailand & 1.84 \\
\hline & & & PRC & 1.06 & PRC & 1.36 \\
\hline & & & Vietnam & 0.402 & Vietnam & 0.538 \\
\hline \multirow[t]{3}{*}{ Malaysia } & 197 & 263 & PRC & 38.1 & PRC & 42.5 \\
\hline & & & Singapore & 28.4 & Singapore & 35.7 \\
\hline & & & United States & 14.7 & United States & 33.1 \\
\hline \multirow[t]{3}{*}{ Myanmar } & 21.3 & 15 & PRC & 8.34 & PRC & 4.46 \\
\hline & & & Singapore & 2.66 & Thailand & 2.66 \\
\hline & & & Thailand & 2.02 & Japan & 1.19 \\
\hline \multirow[t]{3}{*}{ Philippines } & 105 & 99 & PRC & 21.9 & PRC & 20 \\
\hline & & & Japan & 11.6 & Hong Kong & 14.8 \\
\hline & & & South Korea & 8.74 & United States & 13 \\
\hline \multirow[t]{3}{*}{ Singapore } & 293 & 320 & PRC & 42.6 & Hong Kong & 60.8 \\
\hline & & & Malaysia & 35.7 & PRC & 50.3 \\
\hline & & & United States & 25.4 & Malaysia & 28.4 \\
\hline \multirow[t]{3}{*}{ Thailand } & 160 & 215 & PRC & 38.3 & PRC & 40.7 \\
\hline & & & Japan & 26.2 & United States & 28.2 \\
\hline & & & Singapore & 13.4 & Japan & 22 \\
\hline \multirow[t]{3}{*}{ Vietnam } & 204 & 220 & PRC & 70.6 & United States & 46.2 \\
\hline & & & South Korea & 47.7 & PRC & 39.9 \\
\hline & & & Japan & 13.1 & Japan & 18.1 \\
\hline
\end{tabular}

* bn USD

${ }^{* *}$ Data for 2016

\subsection{Chinese foreign direct investment in ASEAN countries and Timor Leste}

In 2017, foreign direct investment flows to ASEAN countries was on the level of 137 billion USD, whereas a year before it was 123 billion USD. Indonesia was the country which noted the highest 
increase of FDI between 2016 and 2017. The largest source of intraregional investment was Singapore $-69 \%$. It was also the largest investor of the region; the second place was taken by Japan, and the third by China. Among the top 30 digital MNEs present in ASEAN in 2016, the Chinese ones were Alibaba Group - metal and mining (selected locations: Indonesia, Malaysia, the Philippines, Singapore, Thailand, Vietnam) and Tencent Holdings - insurance (Indonesia, Malaysia, the Philippines, Singapore, Thailand, Vietnam). China was also on the second place according to active venture capital companies in terms of investments made in the region. China made investment in construction, real estate and finance. Taking into account the destination of investment and the largest investors, in 2017 Chinese companies dominated in Cambodia (77\% of FDI) and Laos (77\% of FDI). The third place was taken by Vietnam (10.1\% FDI). The lowest level of activities was noted in Myanmar ( $0.7 \%$ of FDI). Table 7 illustrates the scale of Chinese FDI in the SEA region.

Table 7. Chinese FDI in SEA states (2013-2018, bn USD) (American Enterprise Institute)

\begin{tabular}{cccccccc}
\hline Country & $\mathbf{2 0 1 3}$ & $\mathbf{2 0 1 4}$ & $\mathbf{2 0 1 5}$ & $\mathbf{2 0 1 6}$ & $\mathbf{2 0 1 7}$ & $\mathbf{2 0 1 8}$ & Total \\
\hline Brunei & 0 & 3.44 & 0.530 & 0 & 0 & 0 & 3.97 \\
Cambodia & 0.660 & 0 & 0.630 & 0.990 & 1.23 & 3.57 & 7.08 \\
East Timor & 0 & 0 & 0.560 & 0 & 0 & 0.490 & 1.05 \\
Indonesia & 1.98 & 4.97 & 8.55 & 3.77 & 7.38 & 3.3 & 29.95 \\
Lao PDR & 1.33 & 0.250 & 3.33 & 6.58 & 3.81 & 3.11 & 18.41 \\
Malaysia & 5.13 & 4.01 & 8.66 & 8.58 & 6.04 & 0.930 & 33.35 \\
Myanmar & 0.300 & 0.370 & 0 & 2.65 & 0 & 1.62 & 4.94 \\
Philippines & 0.600 & 1.21 & 0 & 2.29 & 3.6 & 0.850 & 8.55 \\
Singapore & 1.64 & 1.84 & 4.58 & 4.2 & 14.17 & 2.95 & 29.38 \\
Thailand & 0.110 & 1 & 0.730 & 1.14 & 0.590 & 3.71 & 7.28 \\
Vietnam & 1.24 & 0.210 & 3.52 & 0.420 & 1.4 & 2.41 & 9.2 \\
\hline
\end{tabular}

About the PRC investment examples, in Cambodia Green Leader Holdings Group (Hong Kong, China) launched construction of cassava processing plant and National Petroleum Corporation (China) launched construction of a 620 million USD oil refinery. Moreover, Chinese enterprises also invest in garment and The Bank of China expands its operations. In Laos, PRC invests mostly in hydropower plants and railway construction. In Myanmar, China is investing in mining, production of animals feed, and garment. In turn, photovoltaic cells production was launched in Vietnam in 2017. Enterprises from China developing in the region include Alibaba, which set up a logistics base in Thailand, or Lenovo, which established a regional hub in the same country.

In total cumulative FDI in ASEAN in the period of 2010-2017, percentage share of China was $11.3 \%$ (including Hong Kong), with a value of 106.614 billion USD. At the same time, the share of USA was $12.8 \%$ and 120.988 billion USD. Apparently, the differences between the two countries are not very big. China took the third place in terms of greenfield ICT projects between 2013 and 2017. China also took a high position in terms of M\&A deals in the period of 2014-2017 (ASEAN 2018).

China also makes infrastructure investment in the region to promote the Belt and Road Initiative (BRI). As N. Ganesan emphasises, China [establishes] a number of a road and rail networks to bypass the Strait of Malacca and directly integrate the country into the region. The mentioned infrastructure investment is the following (Ganesan 2018: 1): Malaysia: railways (the East Coast Rail Line) and ports (the port of Kuala Linggi in Malacca); Myanmar: the port of Kyaukphyu in Rakhine state; the dams on the Salwen and Irrawaddy rivers; Thailand: part of the Southeast Asian Belt and Road Initiative.

Investment in Malaysia will help to connect the East and the West Coast of the country, and to develop the Eastern part in particular. Further, China would like to have access to the railway network which connects Singapore and Kunming in Chinese Yunan province. Chinese investment in Malaysia and Myanmar allow for access to the Indian Ocean (Ganesan 2018: 1).

China competes with Japan for infrastructure investment in the region. For instance, China is constructing the Jakarta-Bandung railway section and Japan is modernizing the Jakarta-Surabaya railway connections. In 2017 Japan, following the invitation from India, agreed to develop the 
Asia-Africa Growth Corridor (AAGC), a maritime route which would compete with China's Maritime Silk Road (Brînză 2018). Japan also provided Myanmar with a loan for construction of roads, power plants, ports, and train stations (Hong 2018: 7). However, there are also examples of cooperation between these two countries, such as the high-speed railway which connects Thailand's three main airports: Don Muang, Suvarnabhumi, and U-Tapao (Brînză 2018).

Infrastructure action taken by China are related with the Belt and Road Initiative. At the same time, Japan is developing two projects: the Partnership for Quality Infrastructure for the period 2016-2020, and the Expanded Partnership for Quality Infrastructure for 2017-2021, both in collaboration with the Asian Development Bank. The intended investment amounts to 100 billion USD and 200 billion USD, accordingly (Brînză 2018).

As Hong points out, while some mainland ASEAN countries like Laos and Cambodia view the Sino-Japanese competition as beneficial to their countries in terms of economic capacity-building, some maritime ASEAN countries like the Philippines and Indonesia are more concerned about major-power dynamics as a whole, especially Sino-US relations (Hong 2018: 5). He also describes China's infrastructure diplomacy: Currently, Chinese investment in the ten ASEAN countries is still much lower than that of Japan (...) and various public funds have been set up to support this venture. Chinese projects are managed by state-owned enterprises (SOEs), and are funded with government-provided loans. China is seen as more flexible and can complete infrastructure projects relatively quickly (Hong 2018: 14).

PRC investment is both chance and challenge for less-developed and more fragile and corrupt SEA states. On the one hand, it is an opportunity to build infrastructure and industry, and to boost economic growth. However, there have been cases that Beijing offered loans and investments not only for purely economic purposes. In 2017, the analysis of 'Project Syndicate' stated that China had been using debt to bend other states to its will and unlike International Monetary Fund and World Bank lending, Chinese loans are collateralized by strategically important natural assets with high long-term value (even if they lack short-term commercial viability) (Chellaney 2017). The PRC 'cash for resources' policy is mostly oriented on poor, fragile countries, which need to develop their infrastructure. In return, the PRC demands access to their natural resources and key existing infrastructure (Gopaldas). The Sri Lankan port of Hambantota is given as an example (Chellaney 2017; Gopaldas).

According to John Hurley, Scott Morris and Gailyn Portelance (2018: 152-153), Lao PRD is at high risk of possible debt distress related to the Belt and Road Initiative. Cambodia has been classified as less threatened; however, Chinese investment in this country are also significant. Both Lao PDR and Cambodia are amongst the poorest countries in the region and they have experienced problems related to state fragility and corruption (Table 3). Moreover, the value of public debt (also in relation to GDP) in the region is growing (Table 8), which creates a condition for 'debt-trap diplomacy', especially when a country is less-developed, corrupt and fragile.

Table 8. Public debt in Southeast Asian countries (International Monetary Fund; World Bank)

\begin{tabular}{ccccccc}
\hline & \multicolumn{2}{c}{ Public debt (m USD) } & \multicolumn{2}{c}{ Debt (\% of GDP) } & \multicolumn{2}{c}{ Debt per capita (USD) } \\
Country & 2008 & 2018 & 2008 & 2018 & 2008 & 2018 \\
\hline Brunei & 150 & 351 & $0.94 \%$ & $2.59 \%$ & 401 & 793 \\
Cambodia & 2,792 & 6,998 & $27 \%$ & $28.64 \%$ & 200 & 431 \\
East Timor & 0 & $107^{*}$ & $0 \%$ & 4.28 & 0 & 86 \\
Indonesia & 169,006 & 307,572 & $30.25 \%$ & $30.09 \%$ & 732 & 1,164 \\
Lao PDR & 3,007 & $9,528^{*}$ & $51.72 \%$ & $55.80 \%$ & 509 & 1,370 \\
Malaysia & 95,280 & 199,175 & $39.36 \%$ & $55.57 \%$ & 3,452 & 6,150 \\
Myanmar & 14,701 & 26,194 & $58.56 \%$ & $38.16 \%$ & 300 & 488 \\
Philippines & 90,535 & 128,743 & $52.14 \%$ & $38.92 \%$ & 1,012 & 1,207 \\
Singapore & 186,765 & 416,198 & $97.85 \%$ & $113.63 \%$ & 38,596 & 73,807 \\
Thailand & 102,323 & 209,736 & $34.95 \%$ & $42.08 \%$ & 1,570 & 3,094 \\
Vietnam & 38,742 & $128,357^{*}$ & $39.42 \%$ & $58.22 \%$ & 455 & 1,357 \\
\hline
\end{tabular}

* Data for 2016 


\section{Discussion}

China is gaining importance as a trade partner in the SEA region primarily thanks to exports of goods, and also loans and foreign direct investments. The reasons for China using these economic diplomacy instruments, the role of each of them in target countries, and the effects of these actions both for China and SEA countries should all be analysed. Undoubtedly, the goal of China is to make countries dependent in order to gain access to raw materials or infrastructure, such as ports or railways. This, though, is part of the Belt and Road Initiative. In turn, countries of the region gain support on their path to development thanks to financial resources or support for infrastructural solutions. On the other hand, those countries are gradually becoming dependent on China, especially if they are the less developed and struggle with foreign debt. PRC loans and FDI are becoming an instrument of China's foreign policy and they are enhancing PRC political influence in the region, especially in countries highly dependent on PRC funds.

Further discussion should include detailed presentation of each country in the region, with the influence of economic instruments used by China taken into account. This would allow for obtaining comprehensive knowledge on the methods of selecting these instruments, depending on the situation of particular countries.

\section{References}

ABC News. 2018. Malaysia's Mahathir Mohhamad warns against 'new colonialism' during China visit. Available online:

https://www.abc.net.au/news/2018-08-21/mahathir-says-china-will-sympathise-with-malaysia-problems/10 145750 (accessed on 21 October 2019).

ASEAN. 2018. ASEAN Investment Report 2018 - Foreign Direct Investment and the Digital Economy in ASEAN. Jakarta: ASEAN Secretariat. Available online: https://asean.org/storage/2018/11/ASEAN-Investment-Report-2018-for-Website.pdf $\quad$ (accessed on 05 December 2019).

Ba D. Alice. 2018. Beyond Dichotomous Choices: Responses to Chinese Initiative in Southeast Asia. In Regional Powers and Contested Leadership, Cham: Palgrave Macmillan, pp. 189-227, https://doi.org/10.1007/978-3-319-73691-4

Brînză, Andreea. 2018. Japan's Belt and Road Balancing Act. The Diplomat. Available online: https://thediplomat.com/tag/china-japan-infrastructure-competition/ (accessed on 04 December 2019).

Buckley J. Peter, and Clegg Jeremy, and Cross Adam, and Tan Hui. 2010. China Inward Foreign Direct Investment Success: Southeast Asia in the Shadow of the Dragon. In Foreign Direct Investment, China and the World Economy. UK: Palgrave 239-269. https://link.springer.com/chapter/10.1057/9780230248328

Bünte Marco. 2018. China's Rising Power in Southeast Asia and Its Impact on Regional Institution-Building: Who Is Leading Whom? In Initiatives of Regional Integration in Asia in Comparative Perspective: An Introduction. Netherlands: Springer, pp. 137-154. https://doi.org/10.1007/978-94-024-1211-6_7

Cai, Peter. 2017. Understanding China's Belt and Road Initiative. Lovy Institute for International Policy. Available online: https://www.lowyinstitute.org/publications/understanding-belt-and-road-initiative (accessed on 04 December 2019).

Chen Rong. 2013. A Critical Analysis of the U.S. "Pivot" towards Asia-Pacific: How Realistic is Neo-realism? Connections: 12(3), 39-62.

Chellaney, Brahma. 2017. China's Creditor Imperialism. Project Syndicate. Available online: https://www.project-syndicate.org/commentary/china-sri-lanka-hambantota-port-debt-by-brahma-chellane y-2017-12?barrier=accesspaylog (accessed on 12 December 2019).

Cheng Joseph. 2013. China's Regional Strategy and Challenges in East Asia, Chinas Perspective: 2, 53-65.

Chheang, Vannarith. 2018. China's Economic Statecraft in Southeast Asia. ISEAS - Yusof Ishak Institute. Available online: https://www.iseas.edu.sg/images/pdf/ISEAS_Perspective_2018_45@50.pdf (accessed on 04 December 2019).

Cho Il Hyun, Park Seo-Hyun. 2013. The Rise of China and Varying Sentiments in Southeast Asia toward Great Powers, Strategic Studies Quarterly: 7(2), 69-92. 
Copper F.John. 2016. China's Foreign Aid and Investment Diplomacy in Southeast Asia. In: China's Foreign Aid and Investment Diplomacy, Vol. II. New York: Palgrave Macmillan, pp.1-47, https://doi.org/10.1057/9781137532725_1.

Imbert, Bouyala Florence. 2017. In-Depth Analysis EU economic diplomacy strategy. European Parliament, Directorate-General for External Policies. Available online:

http://www.europarl.europa.eu/RegData/etudes/IDAN/2017/570483/EXPO_IDA(2017)570483_EN.pdf (accessed on 29 November 2019).

Ezrati, Milton. 2018. Weighting The Nation's Fear of China. Forbes. Available online: https://www.forbes.com/sites/miltonezrati/2018/10/18/weighing-the-nations-fear-of-china/\#7f57503d4446 (accessed on 25 November 2019).

Frost Stephen, and Ho Mary. 2005. 'Going Out': The Growth of Chinese Foreign Direct Investment in Southeast Asia and Its Implications for Corporate Social Responsibility. Corporate Social Responsibility and Environmental Management: 12, 157-167, https://doi.org/10.1002/csr.98

Ganesan, Narayanan. 2018. Chinese infrastructure investments in Southeast Asia and their implication for the region. Stiftung Asienhaus. Available online: https://www.eu-china.net/uploads/tx_news/Blickwechsel_Chinese_infrastructure_investments_Ganesan_ Mai2018_01.pdf (accessed on 17 December 2019).

Gopaldas, Ronak. Lessons from Sri Lanka of China's 'debt-trap diplomacy'. Institute for Security Studies. Available online: https://issafrica.org/amp/iss-today/lessons-from-sri-lanka-on-chinas-debt-trap-diplomacy (accessed on 12 December 2019).

Hong, Zhao. 2018. Chinese and Japanese infrastructure investment in Southeast Asia: from rivalry to cooperation? Institute of Developing Economies - Japan External Trade Organization Discussion Paper no. 689. Available online: https://www.ide.go.jp/English/Publish/Download/Dp/689.html (accessed on 04 December 2019).

Horn Sebastian, Reinhart Carmen M., Trebesh Christoph. 2019. China's Overseas Lending. Kiel Working Paper No. $2132 . \quad$ Available online: https://www.ifw-kiel.de/fileadmin/Dateiverwaltung/IfW-Publications/Christoph_Trebesch/KWP_2132.pdf (accessed on 09.12.2019).

Hurley John, Morris Scot, and Portelance Gaylin. 2019. Examining the Debt Implication of the Belt and Road Initiative from a policy perspective. Journal of Infrastructure, Policy and Development: 3(1), 139-175. http://dx.doi.org/10.24294/jipd.v3i1.1123

Lauridsen S. Laurids. 2018. Changing Regional Order and Railway Diplomacy in Southeast Asia with a Case Study of Thailand. In Mapping China's 'One Belt One Road' Initiative, Cham: Palgrave Macmillan, pp. 219-248. https://doi.org/10.1007/978-3-319-92201-0

Lele Ajey. 2012. Space Investments: Southeast Asia. In Asian Space Race: Rhetoric or Reality? Springer India, pp. 109-121. https://doi.org/10.1007/978-81-322-0733-7.

Li Jing, Newenham-Kahindi Aloysius, Shapiro M. Daniel, and Chen Z. Victor. 2013. The two-tier Bargaining Model Revisited: Theory and Evidence from China's Natural Resource Investments in Africa. Global Strategy Journal: 3, 300-321. https://doi.org/10.1111/j.2042-5805.2013.01062.x

Liang Yutian, Zhou Zhengke, and Liu Yi. 2019. Locations Choices of Chinese enterprises in Southeast Asia. The role of the overseas Chinese networks. Journal of Geographical Sciences: 29 (8), 1396-1410. https://doi.org/10.1007/s11442-019-1666-2

Luard Evan. 1984. Economic Relationships among States. London: Palgrave Macmillan.

Malik J. Mohan. 1994. Sino-Indian Rivalry in Myanmar: Implications for Regional Security, Contemporary Southeast Asia: 16(2), 137-156.

Manyin Mark. 2012. Pivot to the Pacific? The Obama Administration's "Rebalancing" toward Asia. Congressional Research Service. Available online: https://fas.org/sgp/crs/natsec/R42448.pdf (accessed on 14 October 2019).

Menon, Rhea. 2018. Thailand's Kra Canal: China's Way Around the Malacca Strait. The Diplomat. Available online: https:/thediplomat.com/2018/04/thailands-kra-canal-chinas-way-around-the-malacca-strait/ (accessed on 18 October 2019).

Morrison, Wayne. 2019. China's Economic Rise: History, Trends, Challenges, and Implication for United States. Congressional Research Service. Available online: https://fas.org/sgp/crs/row/RL33534.pdf (accessed on 14 October 2019). 
OBOReurope. 2019. The new Silk Roads corridors. Available online: https://www.oboreurope.com/en/beltandroad/one-belt/ (accessed on 12 December 2019).

Qi Qin, Cheng Shengkui, Li Fei , Zhang Shuwen, Wu Liang, and Zhang Dan. 2019. Approach to the Geopolitical Influences of Great Powers in Southeast Asia: Case Studies of China and the US. Chinese Geographical Science: 29(2), 341-351. https://doi.org/10.1007/s11769-018-0998-7.

Quer Diego, Rienda Laura, and Andreu Rosario. 2019. Establishment mode choice by Chinese firms in Latin America: The role of host country-specific experience and government official visits. Thunderbird Business Review: 62(1), 1-15. https://doi.org/10.1002/tie.22092.

Samphantharak Krislert. 2011. The Rise of China and Foreign Direct Investment from Southeast Asia. Journal of Current Southeast Asian Affairs: 2, 65-75. https://doi.org/10.1177/186810341103000204

Sinaga C. Lidya. 2018. The Dynamics of Indonesia-China Relations in Politics, Defense-Security, and Economy in Southeast Asia: An Indonesian Perspective. In Six Decades of Indonesia-China Relations. An Indonesian Perspective. Singapore: Springer, pp. 1-15. https://doi.org/10.1007/978-981-10-8084-5

Stuart-Fox Martin. 2004. Southeast Asia and China: The Role of History and Culture in Shaping Future Relations, Contemporary Southeast Asia: 26, 116-139.

Sung Hsing-Chou. 2017. Chinese State Capitalism and China's Geoeconomic Strategy in Southeast Asia. In Chinese Capitalism in Southeast Asia. Cultures and Practices. New York: Palgrave Macmillan, pp. 277-301. https://doi.org/10.1007/978-981-10-4696-4

Swine, Michael D., Tellis, Ashley A. 2000. Interpreting China's Grand Strategy. RAND Corporation. Available online: https://www.rand.org/pubs/research_briefs/RB61.html (accessed on 18 October 2019).

Taj, Hadeeka. 2019. China's New Silk Road or debt-trap diplomacy? Global Risk Insight. Available online: https://globalriskinsights.com/2019/05/china-debt-diplomacy/ (accessed on 12.11.2019).

Song Tao, Liu Weidong, Liu Zhigao, and Wuzhati Yeerken. 2018. Chinese overseas industrial parks in Southeast Asia:An examination of policy mobility from the perspective of embeddedness. Journal of Geographical Sciences: 28(9), 1288-1306. https://doi.org/10.1007/s11442-018-1526-5

Yi Xiaoxiong. 2005. Chinese Foreign Policy in Transition: Understanding China's "Peaceful Development", The Journal of East Asia Affairs: 19(1), 74-112.

Wang Yong. 2016. Offensive for defensive: the belt and road initiative and China's new grand strategy. The Pacific Review: 29(3), 455-463. https://doi.org/10.1080/09512748.2016.1154690

Wang Zheng. 2012. Never Forget National Humiliation. Historical Memory in Chinese Politics and Foreign Relations. New York: Columbia University Press.

Yoshikara Toshii. 2012. China's vision of Its Seascape: The First Island Chain and Chinese Seapower, Asian Politics and Policy: 4(3), 293-314. https://doi.org/10.1111/j.1943-0787.2012.01349.x

Yutian Liang, Zhengke Zhou, and Yi Liu. 2019. Location choices of Chinese enterprises in Southeast Asia: The role of overseas Chinese networks. Journal of Geographical Sciences: 29(8), 1396-1410. https://doi.org/10.1007/s11442-019-1666-2.

Zhong Yu. 2016. The Importance of the Malacca Dilemma in the Belt and Road Initiative, Journal of Policy Science: 10, 85-109.

(C) 2019 by the authors. Submitted for possible open access publication under the terms and conditions of the Creative Commons Attribution (CC BY) license (http://creativecommons.org/licenses/by/4.0/). 